University of Wollongong

Research Online

Faculty of Science - Papers (Archive) Faculty of Science, Medicine and Health

1998

Morphology and process on the lateritic coastline near Darwin, northern Australia

R. W. Young

University of Wollongong

Edward A. Bryant

University of Wollongong, ebryant@uow.edu.au

Follow this and additional works at: https://ro.uow.edu.au/scipapers

Part of the Earth Sciences Commons, Life Sciences Commons, and the Social and Behavioral

Sciences Commons

Recommended Citation

Young, R. W. and Bryant, Edward A.: Morphology and process on the lateritic coastline near Darwin, northern Australia 1998.

https://ro.uow.edu.au/scipapers/136

Research Online is the open access institutional repository for the University of Wollongong. For further information contact the UOW Library: research-pubs@uow.edu.au 


\title{
Morphology and process on the lateritic coastline near Darwin, northern Australia
}

\author{
Abstract \\ Coastal morphology near Darwin is controlled mainly by the gentle warping of a lateritic profile. In \\ synclines the lateritic cuirasse forms extensive shore platforms, but on the anticlines the pallid zone of \\ the weathering profile is eroded by waves, causing the undercut cuirasse to collapse. The dominant \\ modern process on the shore platforms is solutional attack on the laterite, resulting in large depressions. \\ Many of the platforms are covered by relict layers of cemented laterite cobbles transported by waves of \\ high energy. C14 ages on carbonate cement between the cobbles show that one sheet was deposited at \\ about $3700 \mathrm{BP}$ and the other sheet at about $1700 \mathrm{BP}$. Waves generated during devastating tropical \\ hurricanes this century had little effect on the cobble sheets, and they were probably transported onshore \\ by tsunamis originating in the Indonesian archipelago.

\section{Keywords} \\ shore platform formation, laterite, tropics, Darwin, cyclones, tsunami \\ Disciplines \\ Earth Sciences | Life Sciences | Physical Sciences and Mathematics | Social and Behavioral Sciences

\section{Publication Details} \\ This article was originally published as Young, RW, and Bryant, EA, Morphology and process on the \\ lateritic coastline near Darwin, northern Australia, Zeitschrift für Geomorphologie NF, 42(1), 1998, 97-107. \\ Copyright Borntraeger Science Publishers 1998. Original journal information available here
}


Morphology and process on the lateritic coastline near Darwin, northern Australia

by

R. W. YOUNG and E. A. BRYANT, Wollongong, Australia

with 8 figures and 1 table

Summary. Coastal morphology near Darwin is controlled mainly by the gentle warping of a lateritic profile. In synclines the lateritic cuirasse forms extensive shore platforms, but on the anticlines the pallid zone of the weathering profile is eroded by waves, causing the undercut cuirasse to collapse. The dominant modern process on the shore platforms is solutional attack on the laterite, resulting in large depressions. Many of the platforms are covered by relict layers of cemented laterite cobbles transported by waves of high energy. $\mathrm{C}^{14}$ ages on carbonate cement between the cobbles show that one sheet was deposited at about 3700 BP and the other sheet at about 1700 BP. Waves generated during devastating tropical hurricanes this century had little effect on the cobble sheets, and they were probably transported onshore by tsunamis originating in the Indonesian archipelago. 


\section{Introduction}

Lateritic coastlines have received little attention, and are indeed completely ignored in most textbooks on coastal or tropical geomorphology. Their neglect is surprising, for in northern Australia alone approximately $800 \mathrm{~km}$ of coastline is developed on strata with deeply weathered lateritic profiles (GALLOWAY et al. 1984). We describe here the morphology of the coastline developed in lateritic profiles near Darwin and discuss, with particular reference to the undercutting of lateritic cuirasses and to the impact of catastrophic waves, the dominant processes which have shaped it.

\section{Regional setting}

Darwin's climate is classified as seasonally dry tropical (Koppen Aw). Diurnal temperatures range from $34^{\circ} \mathrm{C}$ to $24^{\circ} \mathrm{C}$ between October and April and from $32^{\circ} \mathrm{C}$ to $17^{\circ} \mathrm{C}$ between May and September (McALPINE 1976). Average annual rainfalls range from about $1500 \mathrm{~mm}$ to $1600 \mathrm{~mm}$, with a very marked summer maximum; dry season rainfall rarely exceeds $50 \mathrm{~mm}$. Tropical cyclones with high wind speeds are a major feature of the wet season, and occur at an average frequency of about 1 per year. Cyclone "Tracy", in which wind speeds exceeded $217 \mathrm{~km} / \mathrm{h}$, virtually destroyed the city of Darwin in 1974.

This coast has a macrotidal regime with an annual spring tide range of up to $7 \mathrm{~m}$. During cyclones significant storm surges can develop if they coincide with high tides, but the estimated water level above highest astronomical tide during a storm surge with a 100 year recurrence interval is only $2 \mathrm{~m}$ (HOPLEY \& HARVEY 1979). As the $20 \mathrm{~m}$ isobath generally lies about $20 \mathrm{~km}$ offshore and much energy is lost by waves travelling across the wide shelf, mean wave energy along this coast is low. Waves> $2.5 \mathrm{~m}$ occur $<10 \%$ of the time (DAVIES 1977), although waves in excess of $4 \mathrm{~m}$ are considered possible during major storms (BLAIN, BREMNER \& WILLIAMS 1984). As the coast faces the very tectonically and volcanically active Indonesian archipelago (fig. 1), the potential for significant a tsunami, like the one triggered by the Krakatoa eruption in 1883, seems considerable. Until this study, however, the probable role of tsunami impact on the geomorphology of this coast has been neglected.

The landscape around Darwin is dominated by an undulating surface cut across Proterozoic and Cretaceous rocks at elevations ranging from about 25 to $40 \mathrm{~m}$ above sea level. This surface has been extensively weathered, and in places has lateritic profiles extending to depths $>30 \mathrm{~m}$. Undulations in the lateritised surface closely follow the broad warping preserved in the underlying Cretaceous strata. The coastal edge of this undulating surface therefore consists of cliffs up to $30 \mathrm{~m}$ high on structural highs, and shallow embayments on structural lows (NOTT 1994). Lateritic crusts descend below sea level in the embayments, but are generally perched above the cliffs which are cut in silicified (porcellanite) mottled and pallid zones. 


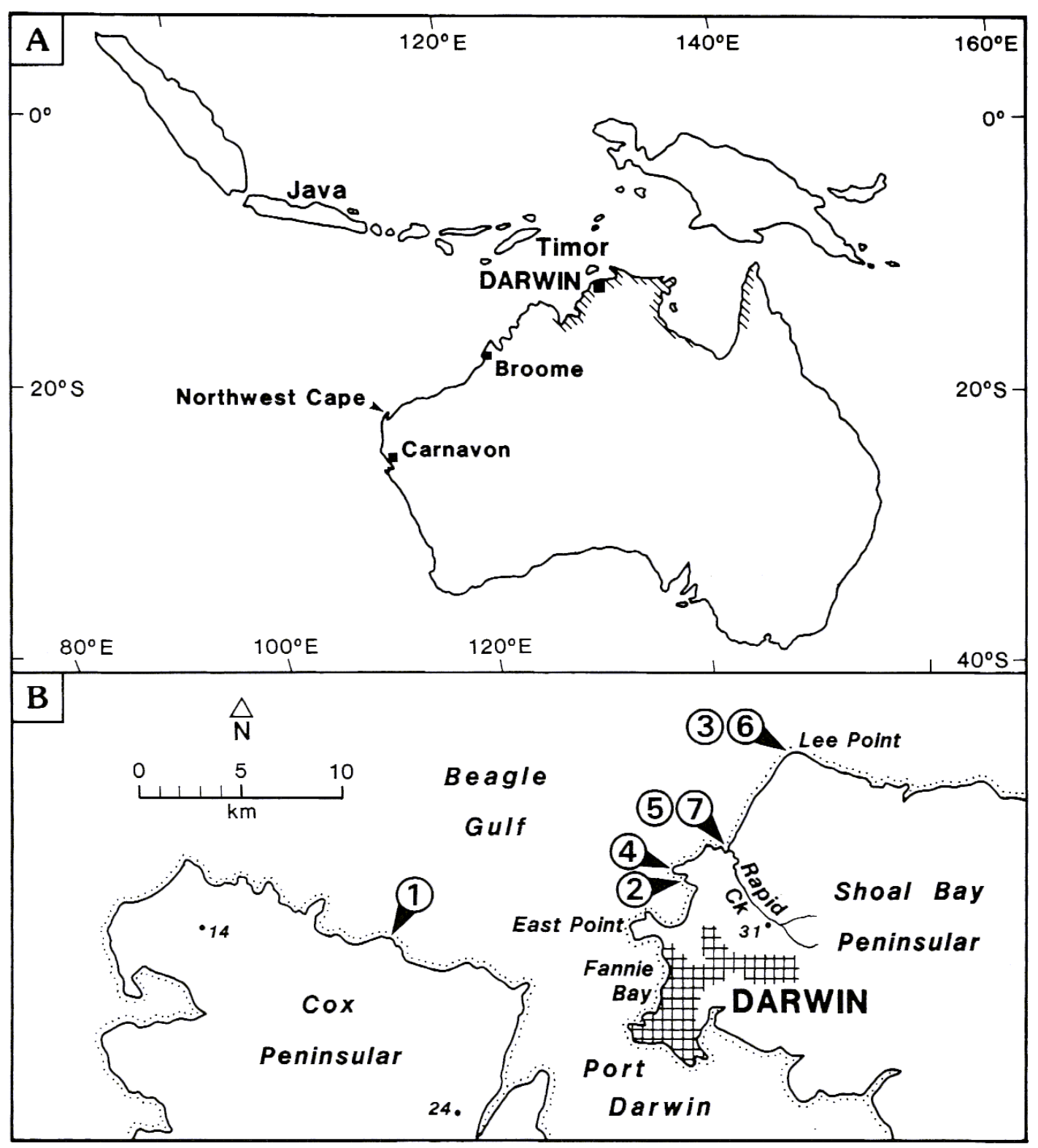

Fig. 1. The Darwin region showing A. the deeply weathered lateritic coast (shaded) and the proximity of the tectonically active Indonesian archipelago B. location of the photos (numbered) and the major lateritic shore platforms described.

\section{Laterite coastal morphology}

N OTT (1994) demonstrated that the configuration of the coastal landforms cut into the lateritic profiles around Darwin is stratigraphically controlled in that the weathering front invariably terminates at a prominent bioturbated bed in the Darwin Member, which is the basal unit of the Early Cretaceous Bathurst Island Formation. NOTT also showed that silica leached from higher in the profile has formed a 1 to 7 $\mathrm{cm}$ thick impermeable layer of quartz at this position which determined the depth of weathering. The variations in the elevation of the warped bioturbated bed in turn determine which part of the lateritic profile outcrops near modern sea level. Where this bed is downwarped so too are the lateritic crusts, which thus form shore platforms or offshore reefs in the structural depressions (fig. 2). Where it is upwarped the pallid 
or mottled zones beneath the crust are exposed to wave erosion and mass failure (fig. 3).

NOTT (1994) also pointed out that the emphasis previously given to a detrital origin for the lateritic crusts near Darwin (HAYS 1967, OLLIER \& GALLOWAY 1990) is not supported by the field evidence. Although some lateritic crusts in this region certainly are detrital, NOTT demonstrated, by tracing sedimentary structures from the under lying Cretaceous strata up into the lateritic profiles, that the majority have formed in situ. We agree with NOTT because sedimentary structures undoubtedly can be traced from the parent rock into the weathering profiles, and because the relatively small detrital layers can be readily distinguished from pisolitic and vermiform crusts developed in situ. Indeed, where there is a substantial detrital component in the laterite forming shore platforms, as at the entrance to the East Point Reserve (fig. 1), the transported pisolites interbedded with calcareous beach rock and have distinctive bedding. Recognition of the dominantly in situ origin of the crusts has an important bearing on the interpretation of the history of marine action on the lateritic shore platforms.

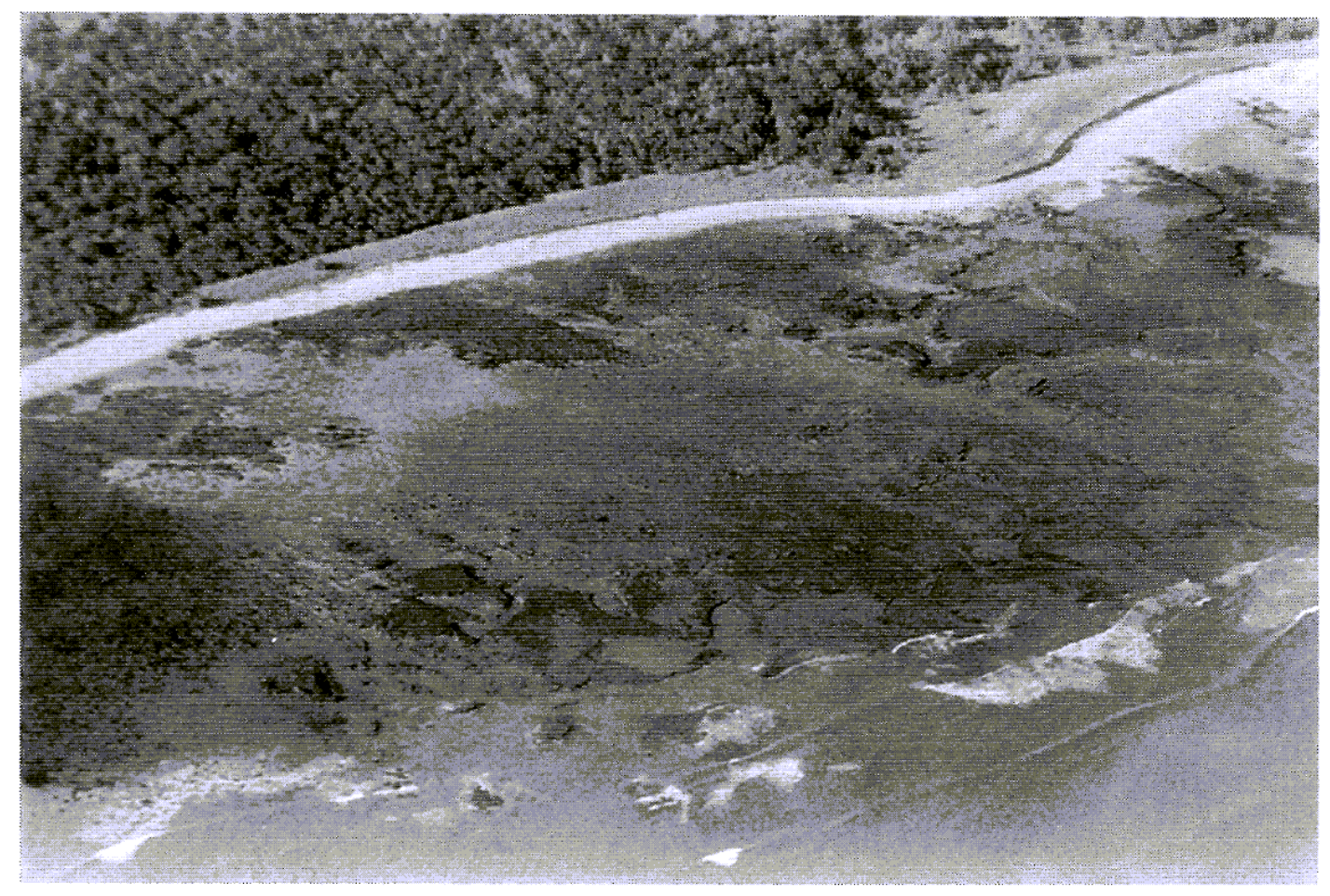

Fig. 2. Laterite shore platform on Cox Peninsula west of Darwin at low tide. Note the large solution depressions developed below the surface of the platform. 


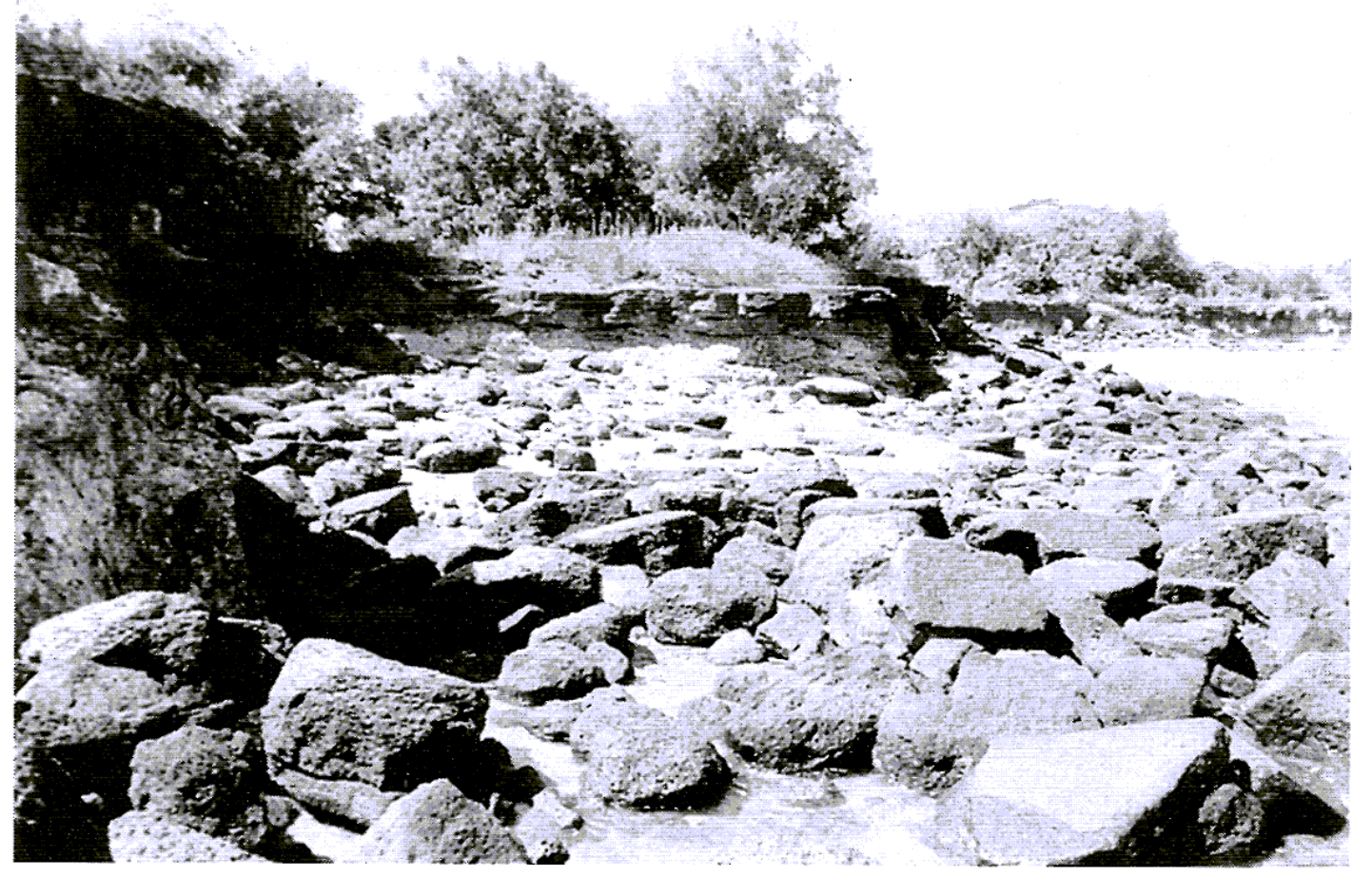

Fig. 3. Undercutting and collapse of the lateritic cuirasse due to wave attack on the mottled zone of the profile. Contrast this scene with the wide shore platform at East Point (photo 5) $0.5 \mathrm{~km}$ down the dip where the cuirasse is at sea level.

\section{Sapping and collapse of laterite shoreplatforms}

Although the hard lateritic cuirasses forming shoreplatforms near Darwin are obviously much more resistant to wave erosion than are the adjacent low cliffs cut in the kaolinitic materials of the pallid zone, they are nonetheless being gradually destroyed. Normal wave erosion is not the key process in this low energy environment, for the array of erosional features such as potholes, pits and small channels usually found on shoreplatforms are poorly developed here. Instead, the platform surfaces are pocked with depressions, into which adjacent blocks have collapsed, in a fashion superficially similar to, although at a much smaller scale than the features which McFARLANE \& TWIDALE (1987) have refered to as lateritic karst. The link between lateritic karst and the solution depressions on the platforms is demonstrated by the presence of solution pits, identical to the smaller features described by McFARLANE and TWIDALE occur in lateritic crusts immediately behind and above the level of some of the shoreplatforms at Darwin.

The depressions in the lateritic platforms have irregular shapes, vary in diameter (long axis) from about $0.5 \mathrm{~m}$ to about $8 \mathrm{~m}$, and are generally about $0.5 \mathrm{~m}$ deep (fig. 4). There seems to be no preferential position for their development on the platforms, as might be expected if they were the product of wave erosion. Indeed at East Point the largest depressions lie at the rear of an extensive platform where wave action is min- 


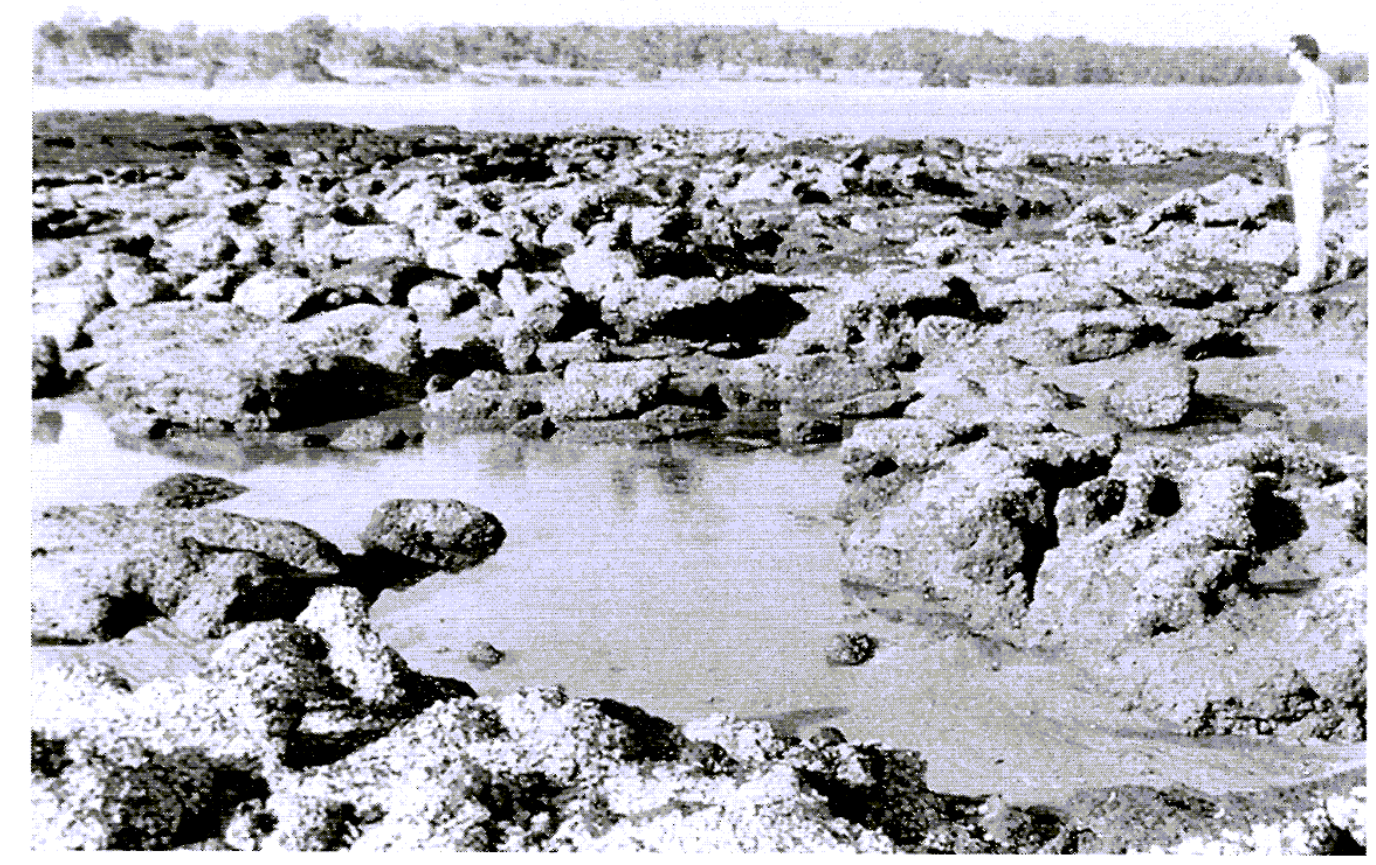

Fig. 4. An elongated solution depression in the lateritic shore platform on Lee Point at low tide. Note the irregular shape of the depression, the almost total absence of lateritic debris in it, and the cemented cobbles on the surface of the platform.

imal (fig. 5). The removal of all except small fragments of the lateritic crusts from enclosed basins leaves little doubt of the dominance of solutional processes.

On some platforms, especially the platform adjacent to the mouth of Rapid Creek platform (fig. 1), part of the cuirasse has broken into a mosaic of tilted blocks without the development of substantial intervening depressions (fig. 6). Sapping of the kaolinised sediments from beneath the cuirasse, rather than corrosion of the cuirasse itself, must be the dominant process in this case. The extremely close interlocking of the blocks rules out any possibility of transport by waves; the blocks have simply fractured and tilted as the substrate has been removed. Indeed, fig. 6 shows a clear distinction between the interlocking mosaic of angular, collapsed blocks and the sheet of sub-rounded cobbles cemented to the intact platform surface.

Solutional disintegration of laterite is now well documented, although this is the first instance known to us in which it has been reported from a shoreline setting. As McFARLANE and TWIDALE (1987) point out: "There is now a substantial body ofevidence to indicate that dissolution of lateritic minerals is sufficient to cause the development ofa wide range ofkarst features on various scales. Haematite, goethite, gibbsite, kaolinite and quartz, relatively resistant though they may be to dissolution, are nevertheless susceptible under some conditions." Even casual observation of the Darwin shore platforms indicates that this susceptibility is increased in the tidal zone.

Although crystallization pressure of salt may be a contributing factor to the disintegration of the lateritic curiasse, we suggest that the process is predominantly chemical rather than physical. The enhanced solubility of iron in seawater, which is an excellent electron-transfer medium, is well known, and needs no further comment here other than to say that it is strikingly illustrated by the fusing of military hardware, dumped off the cliffs near Darwin at the end of World War II, into a single corroded sheet. Laboratory results have clearly demonstrated that the presence of $\mathrm{NaCI}$ has a strong accelerating effect on the rate of dissolution of $\mathrm{SiO}_{2}$ (VAN LIER et al. 1960), and that increasing cWoride or sulfate concentration accelerates this dissolution of $\mathrm{SiO}_{2}$ both in its crystalline and amorphous forms (YARIV \& CROSS 1979, KASTNER 1981). Moreover, YOUNG (1987) has presented Scanning Electron 
Microscope evidence which strongly indicates that high concentrations of salt in coastal environments result in chemical corrosion of quartz grains.

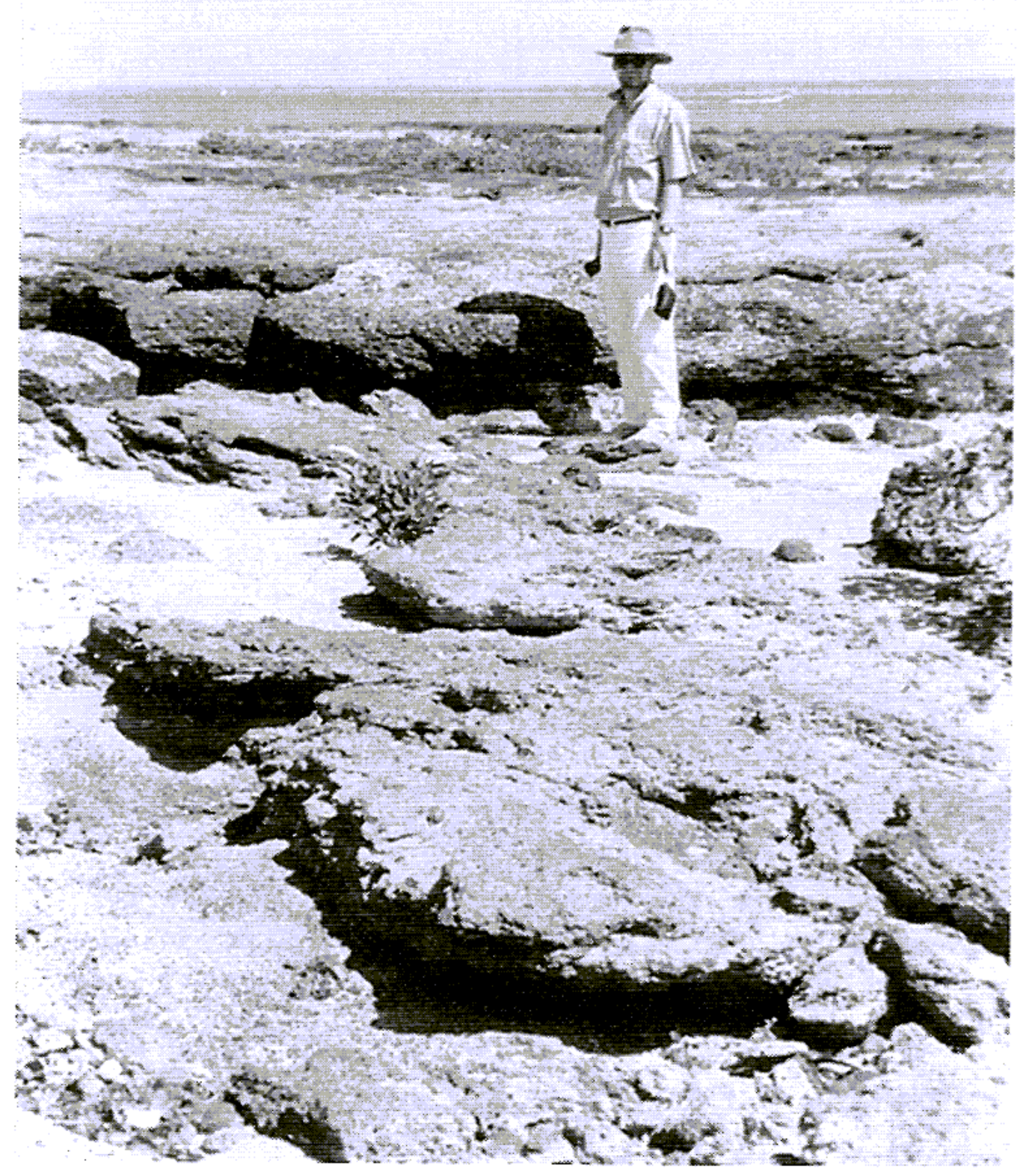

Fig. 5. A large solution depression developed in a sheltered site at the rear of the platform on the cuirasse at East Point. Note again the almost complete absence of lateritic debris. 


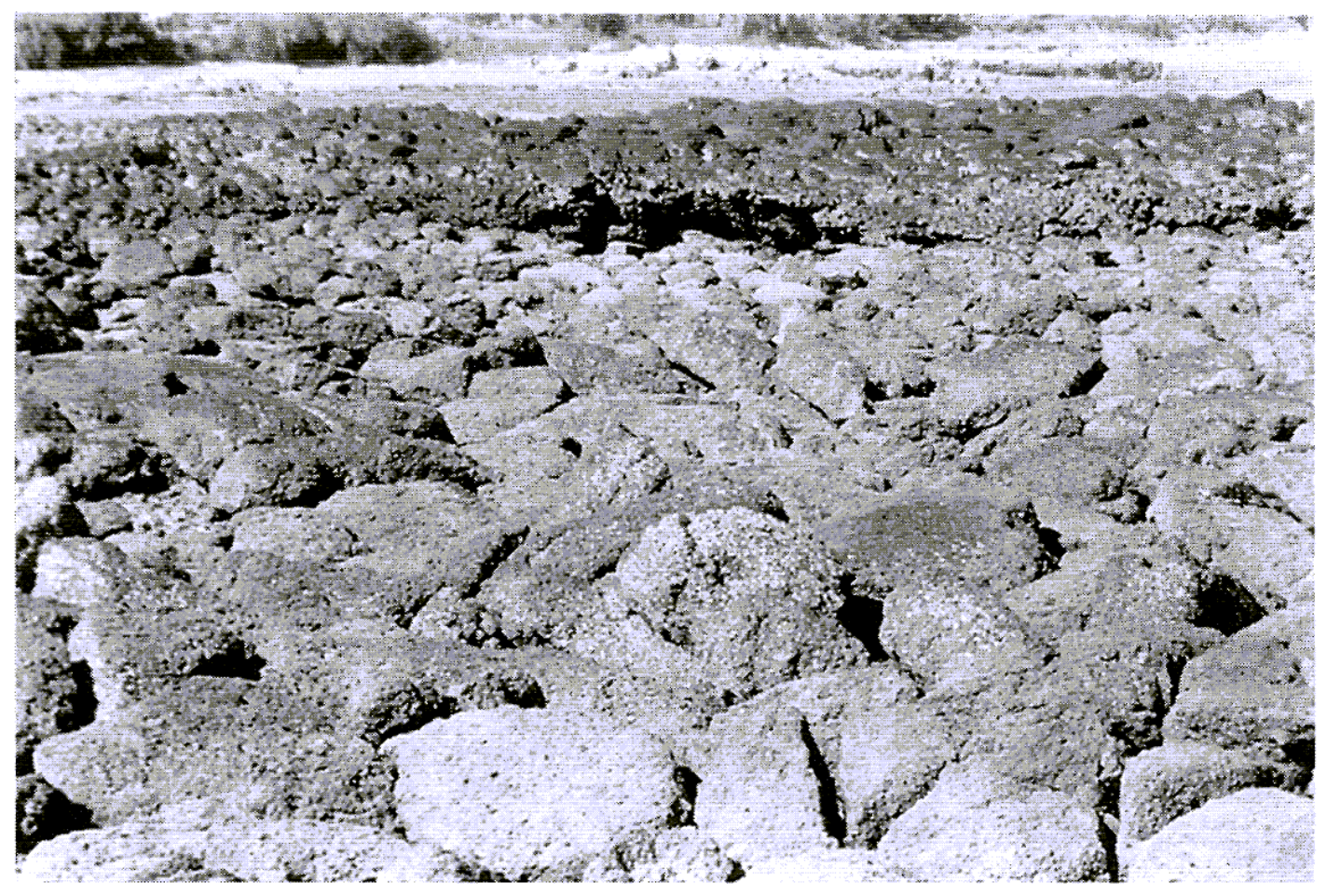

Fig. 6. A mosaic of interlocking blocks of laterite on the platform at Rapid Creek. The platform surface here has collapsed due to the sapping of the underlying clayey regolith. The blocks have tilted, but have not been transported from their original location. Contrast the sub-rounded cobbles in the background which were transported onshore and cemented onto the surface of the platform.

\section{Characteristics of the cobble sheets}

Although solution seems to be the dominant process in the disintegration of the lateritic shore platforms under normal low energy conditions along the Darwin coast, the presence of two distinct sheets of cemented cobbles on most of these platforms leaves no doubt of the impact, albeit infrequent, of wave action of considerable magnitude. These two sheets o(cobbles are composed mainly of rounded to subrounded fragments of laterite which have been apparently transported $100 \mathrm{~m}$ to $200 \mathrm{~m}$ from laterite reefs offshore. They are preserved particularly well on the platforms at Lee Point and at Rapid Creek (fig. 7), but can be seen on several platforms near East Point. Sheets of cobbles occur also on platforms cut in the pallid zones of the lateritic profiles, especially immediately north of the Darwin Yacht Club in Fannie Bay, though in these cases the clasts are dominantly porcellanite rather than laterite. 


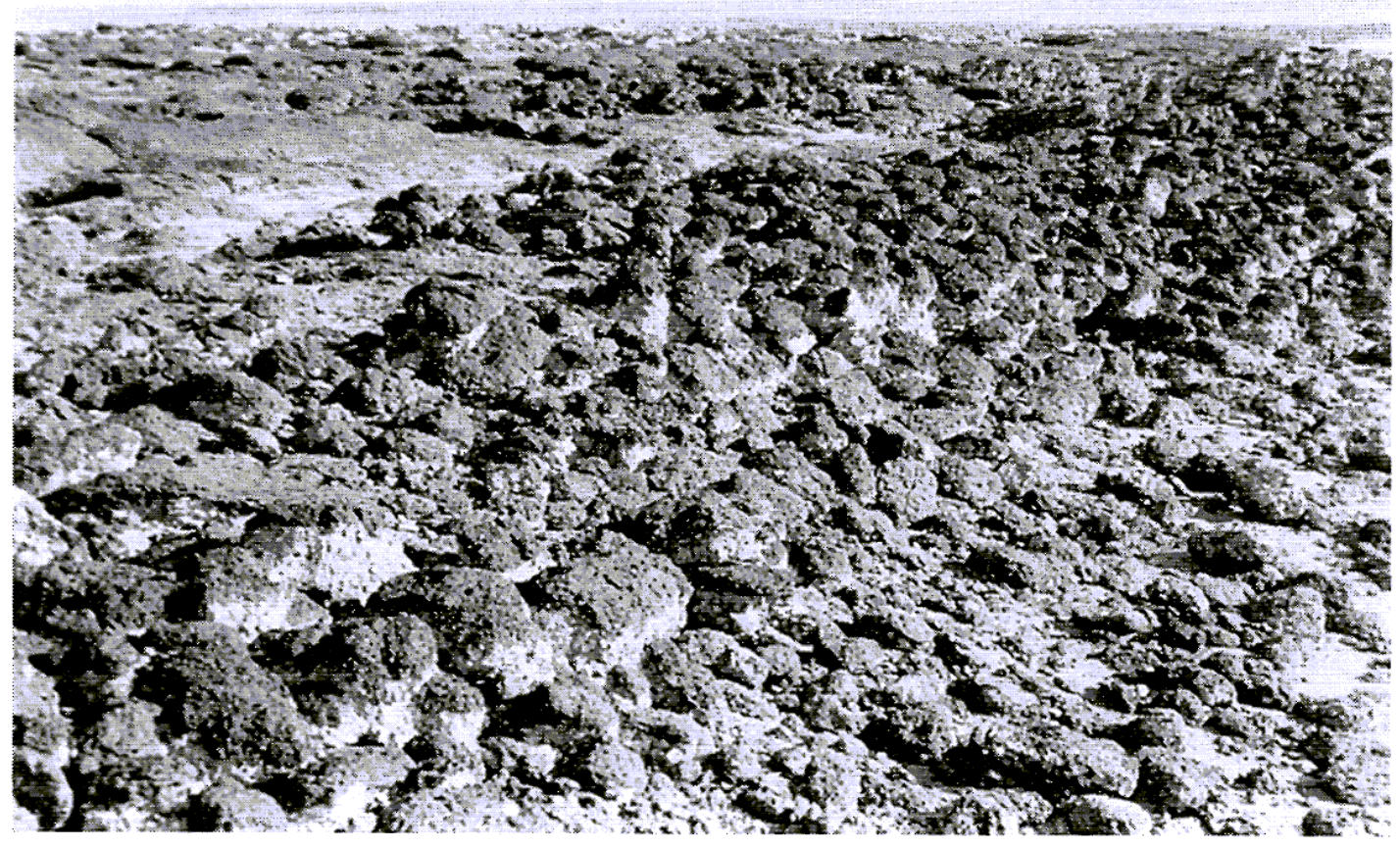

Fig. 7. Layer of sub-rounded lateritic cobbles $1.5 \mathrm{~m}$ thick which were transported onshore and cemented by carbonate to the platform. Only minor erosion seems to have occurred since the cobbles were deposited, even during Cyclone Tracey which devastated Darwin.

The occurrence of two distinct phases of cobbles accumulation can be readily demonstrated from the contrasts in size, shape, mode cementation and the clear superimposition of one sheet upon the other (fig. 8). At Rapid Creek the lower sheet consists of rounded laterite clasts which range on the b axis from only 4 to $16 \mathrm{~cm}$ with a mean size of $9 \mathrm{~cm}$. The upper sheet consists of sub-angular laterite clasts with $a \mathrm{~b}$ axis range of 20 to $60 \mathrm{~cm}$ and a mean of $40 \mathrm{~cm}$. And whereas the lower sheet is cemented by fine carbonate containing coral fragments, the upper sheet is cemented mainly by oyster shell with smaller amounts of fine carbonate. Similar contrasts occur in the two sheets of cobbles at Lee Point.

These sheets of cobbles are relict and have no active counterparts. Both sheets have been eroded, and in places have vertical scarps 1 to $1.5 \mathrm{~m}$ high cut into them on the landward side (fig. 7). Moreover, as they do not extend into the large depressions, but are limited to the undulating surfaces of the laterite platforms (figs. 4 and 5), they must predate the dominantly solutional regime now operating.

\section{Age and origin of the cobble sheets}

$\mathrm{C}^{14}$ analyses of the carbonates cementing the laterite clasts yielded ages of $1680 \pm 60$ (Beta 79069) for the upper sheet of cobbles and $3679 \pm 70$ (Beta 79068) for the lower sheet at Lee Point. These ages are corrected for oceanic reservoir effects and $\mathrm{C}^{13} / \mathrm{C}^{12}$ ratios.

The character and age of the cobble sheets may perhaps throw important new light on the cyclonic history of the Darwin area. If they were indeed emplaced by waves generated by tropical cyclones, even allowing for variations in fetch of wavegenerating winds, those events must have been of much greater magnitude than the Cyclone Tracy which devastated Darwin in 1974. Tracy did not mobilise clasts like those in the relict sheets, nor did it apparently do much to eroded those sheets because 
air photos flown in 1969 show the main cobble outcrops essentially as they are today. Therefore, as the clasts in the upper sheet have b-axis much larger than those of clasts in the lower sheet, they presumably record the event of greatest magnitude to strike the Darwin area in approximately the last 3500 years. The lower sheet could likewise be interpreted as recording the 1500 year cyclonic event. Yet caution is needed because the cobbles may have been emplaced not by waves generated by storms, but by tsunamis.

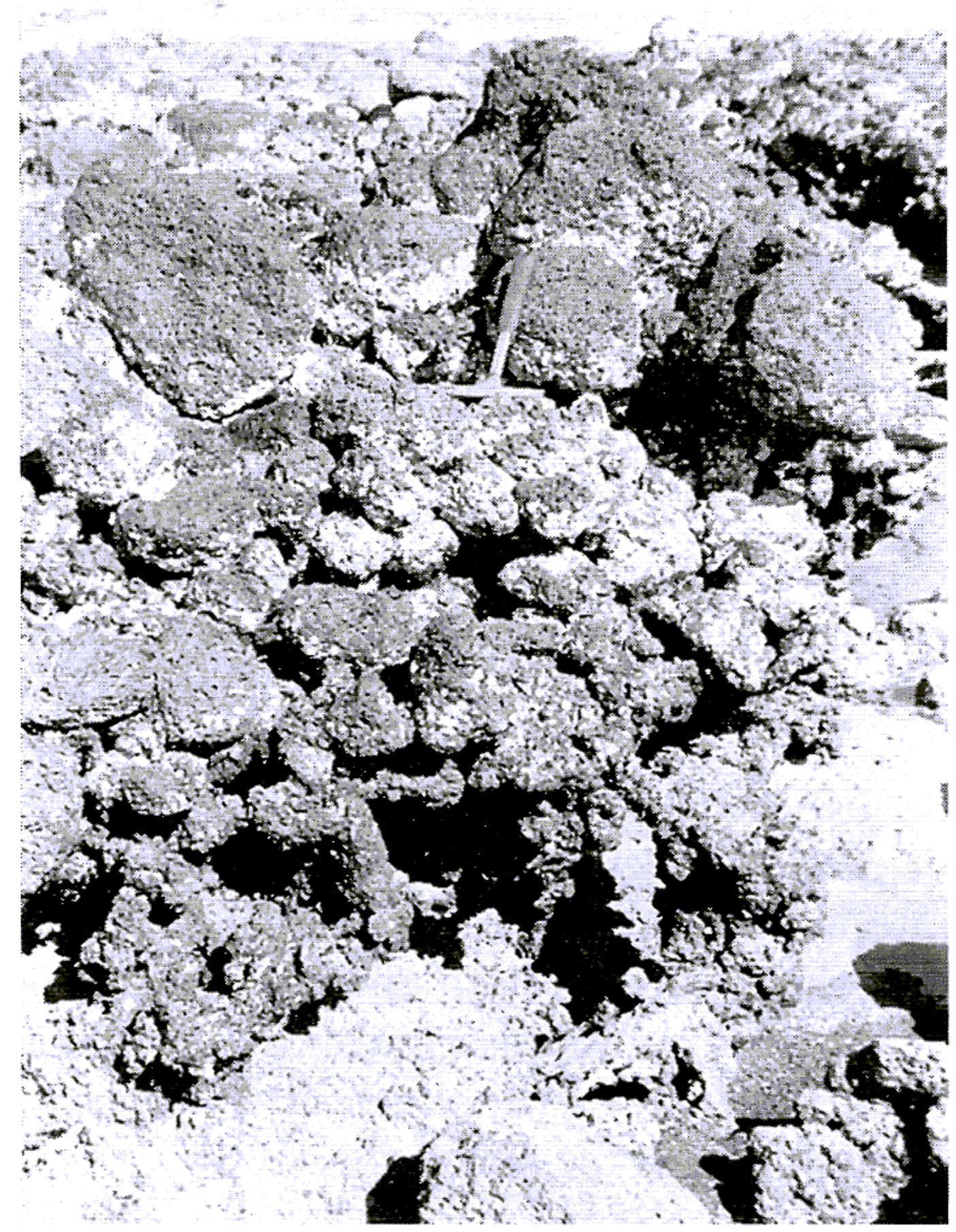

Fig. 8. Two sheets of cemented cobbles separated by an unconformity (head of the hammer). The carbonate cements yielded $\mathrm{C}^{14}$ ages of $3679 \pm 70$ for the lower sheet of 
smaller cobbles and of $1680 \pm 60$ for the upper sheet of larger cobbles. These sheets apparently record the impact of tsunamis generated in the Indonesian Archipelago.

The likely role of tsunamis was forced home when, in June 1994, while we were conducting our field research at Darwin, the tsunami which took over 200 lives on the southern coast of Java struck the northwest coast of Australia, from Broome to Carnavon (fig. 1), within three to four hours of being generated by an earthquake of magnitude $\mathrm{Mw}$ 7.7. The description of its impact on a beach and car park at Northwest Cape (fig. 1) provides a plausible modern analogue for the onshore transport of the laterite cobbles at Darwin. "A surge estimated at 3 to $4 \mathrm{~m}$ carried hundreds offish, as well as crayfish, rocks and coral inland for a distance of two to three hundred meters. The force of the water uprooted part of the car park's rail fence" (FOLEY 1995). FOLEY comments that, although tsunamis occur infrequently in this area of Australia, the tsunami of June 1994 demonstrates "the vulnerability of any coastline exposed to tsunami is, whether of local or distant origin." The Darwin coastline would certainly be vulnerable to tsunamis generated at the eastern end of the tectonically very active Indonesian archipelago.

Table $1 \quad \mathrm{C}^{14}$ ages on carbonate cement in the cobble sheets on the shore platform at Lee Point.

\begin{tabular}{llll}
\hline Lab. No. & Measured $C^{14}$ age* & $\mathrm{C}^{13} / \mathrm{C}^{12}$ ratio & Conventional $\mathrm{C}^{14}$ age \\
\hline Beta 7068 & $3250 \pm 60$ & $+0.60 / 00$ & $3670 \pm 70$ \\
Beta 79069 & $1250 \pm 60$ & $+1.20 / 00$ & $1680 \pm 60$ \\
\hline
\end{tabular}

* Adjusted for oceanic reservoir effects.

The characteristics of the cobble sheets seem indicative of emplacement by tsunamis. Although the size of the cobbles demonstrates wave power far exceeding that of modern cyclones, the lack of sorting, or indeed any other readily discernable internal structure apart from crude imbrication, is probably best explained in terms of a short burst of high energy, characteristic of a single wave or a train of several tsunami waves. Similar transport, albeit of much larger blocks, has been attributed to tsunamis along the southeastern coast of Australia (YOUNG et al. 1995). For the Darwin region the general westerly approach of the waves, indicated by the imbrication of the cobbles, points to the most probable source area being near Timor (fig. 1).

\section{Conclusions}

Three major conclusions can be drawn from this reconnaissance study of Darwin coastline.

1. The morphology is largely controlled by the localized warping of the lateritic curiasse relative to the present range of wave erosion. In the synclines the cuirasse forms the surface of shore platforms; in the anticlines the cuirasse is undercut by erosion of the kaolinised pallid zone of the weathering profile.

2. Notwithstanding the relatively high chemical resistance of the cuirasse, the dominant process operating on the platforms under the modern low energy wave regime is the solutional etching of large depressions. This process can be considered 
as the coastal counterpart of the lateritic karst development described by McFarlane and Twidale from many parts of the tropics.

3. Relict sheets of lateritic cobbles cemented on the surfaces of the platforms are indicative short phase of high energy wave action. If these waves were generated by storms, those storms must have been of far greater magnitude than Cyclone Tracey which destroyed Darwin in 1974. We believe that the sheets of cobbles record instead the impact of two significant tsunamis which were probably generated in the vicinity of Timor, and which struck this coast at about 1600 and 3600 B.P.

These conclusions from the Darwin area emphasise the importance both of climatic and tectonic settings in deciphering coastal history in the tropics.

\section{References}

BLAIN, BREMNER \& WILLIAMS PTY. LTD. (1984): Greater Darwin storm surge study. - Northern Territory Depart. Lands, Darwin.

DAVIES, J. L. (1977): Geographical variation in coastal development. - Longman, London, $204 \mathrm{pp}$.

FOLEY, G. (1995): June 2, 1994 tsunami in Australia. - Tsunami Newsletter 27, 1: 910.

GALLOWAY, R. W., R. STORY, R. COOPER \& G. A. YAPP (1984): Coastal lands of Australia. CSIRO Nat. Res. Ser. 1: 1-53.

HAYS, J. (1967): Land surfaces and laterites in the north of the Northern Territory. In: JENNINGS, J. N. \& J. A. MABBUTT (ed.): Landform studies from Australia and New Guinea: 182-210, ANU, Canberra.

HOPLEY, D. \& N. HARVEY (1979): Regional variations in storm surge characteristics around the Australian coast: a preliminary investigation. - In: HEATHCOTE, R. L. \& B. G. THOM (ed.): Natural hazards in Australia: 164-189, Australian Academy of Science, Canberra.

KASTNER, M. (1981): Authigenic silicates in deep sea sediments. - In: EMILIANI, C. (ed.): The oceanic lithosphere: 915-980, Wiley, New York.

McALPINE, J. R. (1976): Climate and water balance. - CSIRO Land Res. Ser. 38: 3549.

McFARLANE, M.J. \& C. R. TWIDALE (1987): Karstic features associated with tropical weathering profiles. - Z. Geomorph. N.F., Suppl. 64: 73-96.

NOTT, J. F. (1994): The influence of deep weathering on coastal landscape development in the monsoonal tropics of northern Australia. - J. Geol. 102: 509-522.

OLLIER, C. D. \& R. W. GALLOWAY (1990): The laterite profile, ferricrete and unconformity. Catena 17: 97-109.

VAN LIER, J. A., P. L. DE BRUYN \& J. OVERBEEK (1960): The solubility of quartz. - J. Phys. Chem. 64: 1675-1682.

YARIV, S. \& H. CROSS (1979): Geochemistry of colloid systems. - Springer, Heidelberg, $450 \mathrm{pp}$.

YOUNG, A. R. M. (1987): Salt as an agent in the development of cavernous weathering. - Geology 15: 962-966.

YOUNG, R. W, E. A. BRYANT \& D. M. PRICE (1995): Catastrophic wave (tsunami) transport of boulders in southern Ne, South Wales, Australia. - Z. Geomorph. N. F. 40: 191-207.

Address of the authors: R. W. YOUNG and E. A. BRYANT, School of Geoscience, University of Wollongong, 2522, Australia. 